Similar prospective studies in cohorts of patients with persistent generalised lymphadenopathy in the United States have reported rates of progression from $6 \%$ to $19 \%$ during median follow up times from 12.9 to 22 months. ${ }^{1}$ The rates of progression in cohorts of patients infected with HIV with and without lymphadenopathy ranged from $8 \%$ to $34 \%$ over three years. ${ }^{2}$ In a cohort of 1835 infected homosexual men followed up for a median of 15 months the annual incidence of AIDS in asymptomatic men compared with that in men with lymphadenopathy was not significantly different. ${ }^{3}$ Prognostic markers for disease progression include clinical features such as fever and weight loss, oral candida, and leucoplakia, haematological and immunological abnormalities such as anaemia, cytopenias, particularly progressive depletion of $T$ helper lymphocytes, increased serum IgA concentrations, impaired in vitro $\gamma$-interferon production, lymphocyte responses to pokeweed mitogen, and perhaps specific cellular responses to HIV. ${ }^{34}$ More recently, a decline in the titre or the disappearance of anti-P24 (the antibody to HIV core protein) has been shown to predate the development of the full blown syndrome by up to 27 months. $^{5}$

Many complex tests are not widely available to the general physician, and our study shows that a clinical examination and simple haematological measurements are useful in determining the risk of progression.

The cohort studies at the Middlesex Hospital are supported by the Medical Research Council. We thank Mr P Williams for statistical advice and Dr R S

Tedder and his colleagues in the virology section, microbiology department, Middlesex Hospital and University College Hospital.

1 Weller IVD. The AIDS virus: a new human immune deficiency retrovirus and the natural history of infection. In: Triger DR, ed. Royal College of Physicians of London. Advanced medicine. Vo 22. London: Baillière, Tindall, 1986: 141-53.

2 Goedert JJ, Biggar RT, Weiss SH, et al. Three year incidence of AIDS in five cohorts of HTLV-II infected risk group members. Science 1986;231:992-5.

3 Polk BF, Fox R, Brookmeyer R, et al. Predictors of the acquired immunodeficiency syndrome developing in a cohort of seropositive homosexual men. $N$ Englf Med 1987;316:61-6.

4 Anonymous. Who will get AIDS? Lancet 1986;ii:953-4.

5 Weber JN, Clapham PR, Weiss RA, et al. Human immunodeficiency virus infection in two cohorts of homosexual men: neutralising sera and association of anti-gag antibody with prognosis. Lancet $1987 ; \mathrm{i}: 119-22$.

(Accepted 27 February 1987)

Academic Department of Genito-Urinary Medicine, Middlesex Hospital Medical School, London W1N 8AA

C A CARNE, MB, MRCP, lecturer

I V D WELLER, MD, MRCP, Wellcome Trust senior lecturer in infectious diseases

C LOVEDAY, MB, PHD, lecturer

$M$ W ADLER, MD, FRCP, professor

Correspondence and requests for reprints to: Dr I V D Weller, Academic Department of Genito-Urinary Medicine, James Pringle House, Middlesex Hospital, London W1N 8AA.

\section{A forgotten factor in pelvic inflammatory disease: infection in the male partner}

Infection by Chlamydia trachomatis has been increasingly implicated in pelvic inflammatory disease in women. ${ }^{12}$ While we recognise that pelvic inflammatory disease is often sexually transmitted, we know little about the sexual partners of women with the disease. $C$ trachomatis has been isolated in up to half of all men with non-gonococcal urethritis. ${ }^{3}$ Because some of these patients are asymptomatic they may fail to seek medical treatment and therefore spread the infection.

\section{Methods and results}

We studied women who presented at a sexually transmitted disease clinic with features of pelvic inflammatory disease. Their sexual partners in the previous three months were asked to attend for investigation.

All patients were seen by the duty doctor. A full clinical and sexual history was taken. Routine screening for Neisseria gonorrhoeae, Trichomonas vaginalis, yeasts, and syphilis was performed for all women. ${ }^{4}$ For technical reasons $C$ trachomatis culture could not be carried out for all the women. Each patient underwen bimanual pelvic examination. The criteria for diagnosing pelvic inflammatory disease weres: (a) lower abdominal pain with or without vaginal discharge, $(b)$ adnexal tenderness with or without adnexal mass, and $(c)$ positive cervical excitation.
Ultrasonography and laparoscopy were performed in three patients because of severe or equivocal physical signs.

Tests on the male contacts were performed only if they had held their urine for over four hours. Non-gonococcal urethritis was diagnosed if a Gram stained urethral smear contained 10 or more polymorphonuclear cells per field (1000 magnification) and microscopy and culture failed to show $N$ gonorrhoeae. ${ }^{4}$ Chlamydia cultures were taken from most of the male contacts.

Statistical comparisons were by the $\chi^{2}$ test (with Yates's correction where indicated).

Fifty eight women were diagnosed as having pelvic inflammatory disease. Of the 45 in whom chlamydia cultures were taken, $16(36 \%)$ gave positive results. One male contact for each of the $\mathbf{5 8}$ women was seen. Forty six of these men had non-gonoccocal urethritis, of whom 36 were symptom free. The remainder complained of slight urethral discharge or dysuria. $C$ trachomatis was isolated from 10 of the 36 cultured, seven of whom were asymptomatic.

Six women admitted to having had a second male partner in the previous three months but these could not be traced. In addition, 11 men admitted to having had another female partner. There appeared to be no relation between concurrent sexually transmitted disease and pelvic infection or non-gonococcal urethritis.

Eleven of the patients with positive chlamydia cultures were taking oral contraceptives in contrast to seven of the 29 with negative chlamydia cultures $\left(\chi^{2}=40.07, p<0.001\right)$. Only four patients were using an intrauterine contraceptive device.

\section{Comment}

The isolation of $C$ trachomatis from the cervixes of $36 \%$ of women with pelvic inflammatory disease confirmed studies from Scandinavia and the United Kingdom which showed a $30-40 \%$ rate in pelvic infection diagnosed at laparoscopy. ${ }^{12}$ The present study emphasises the high incidence of non-gonococcal urethritis among the male partners of women with pelvic inflammatory disease, over three quarters of whom were asymptomatic. Kinghorn et al studied women with more severe pelvic inflammatory disease than those reported here and showed that $56 \%$ of their male contacts had asymptomatic non-gonococcal urethritis. ${ }^{2}$ Our study highlights the need to trace the sexual contacts of all women with pelvic inflammatory disease.

We thank the staff of the Department of Virology, St Thomas's Hospital for performing the chlamydia cultures.

1 Ripa KT, Svenson L, Treharne JD, Westrom L, Mardh PA. Chlamydia trachomatis in patients with laparoscopically verified salpingitis as a result of isolation and antibody determination. $A m \mathcal{F}$ Obstet Gynecol 1980;138:960-4.

2 Kinghorn GR, Duerden BI, Hafiz S. Clinical and microbiological investigation of women with acute salpingitis and their consorts. Br $\mathcal{J}$ Obstet Gynaecol 1986;93:869-80.

3 Holmes K, Handsfield $\mathrm{H}$, Wang SP, et al. Etiology of non-gonococcal urethritis. N Engl 7 Med 1975;292:1199-205.

4 Forslin L, Falk V, Danielsson D. Changes in the incidence of acute gonococcal and non-gonococcal salpingitis. Br f Vener Dis 1978;54:247-50.

5 Bradbeer CS, Thin RNT. Comparison of econazole and isoconazole as a single-dose treatment for vaginal candidiasis. Genitourinary Medicine 1985;61:396-8.

(Accepted 19 January 1987)

Department of Genitourinary Medicine, St Thomas's Hospital, London SE1 7EH

MARTHA JACOB, MB, BS, research registrar

MOHSEN SHAHMANESH, MD, MRCP, senior registrar

JULIE WHATLEY, SRN, BSC, research nurse

NICOL THIN, FRCP, consultant physician

Correspondence to: Dr Shahmanesh.

\section{Adverse reactions to drugs in children}

Most studies of adverse reactions to drugs in children have observed those who received drugs in hospital or at home shortly before admission. ${ }^{1.3}$ As the use of drugs in hospital is considerably different from that outside ${ }^{245}$ the incidence and nature of adverse reactions might also be expected to vary.

We aimed to discover the incidence and nature of adverse reactions to drugs in a large group of children considered to be representative of the total child population.

\section{Subjects, methods, and results}

We surveyed 1590 children over two periods of 13 weeks in the summer and winter of 1984-5. They were pupils or siblings of pupils attending 19 infant care or educational establishments around Birmingham. Parents were asked to record on a weekly questionnaire the drugs being taken by their children, both prescribed and non-prescribed, and whether adverse reactions to the drugs had been seen. 
Drugs causing adverse reactions

\begin{tabular}{|c|c|c|c|c|}
\hline Drug & $\begin{array}{l}\text { No of courses } \\
\text { of drug }\end{array}$ & $\begin{array}{l}\text { No of adverse } \\
\text { reactions } \\
(n=235)\end{array}$ & $\begin{array}{l}\text { Incidence (\%) of } \\
\text { adverse reactions per } \\
\text { drug course }\end{array}$ & $\begin{array}{l}\text { Adverse drug reactions in order of incidence } \\
\text { (figure in parentheses gives No of events if }>1) \\
\qquad(n=239)\end{array}$ \\
\hline \multicolumn{5}{|c|}{ Antibacterials } \\
\hline Amoxycillin & 119 & 15 & 13 & $\begin{array}{l}\text { Diarrhoea (7), drowsiness (4), rash, headache, } \\
\text { hyperactivity, anorexia }\end{array}$ \\
\hline Cephalexin & 25 & 4 & 16 & Diarrhoea (3), drowsiness \\
\hline Erythromycin & 69 & 9 & 13 & Diarrhoea (5), drowsiness (2), rash (2), abdominal pain \\
\hline Flucloxacillin & 3 & 1 & 33 & Vomiting \\
\hline Phenoxymethylpenicillin & 41 & 7 & 17 & Rash (3), diarrhoea (2), drowsiness (2) \\
\hline \multicolumn{5}{|c|}{ Respiratory (excluding decongestants and cough linctuses) } \\
\hline Aminophylline & 3 & 1 & 33 & Hyperactivity \\
\hline Prednisolone & 6 & 5 & 83 & Abdominal pain (3), diarrhoea (2) \\
\hline Salbutamol & 75 & 5 & 7 & Shakiness (2), dizziness, irritability, sleep disturbance \\
\hline \multicolumn{5}{|c|}{ Gastrointestinal } \\
\hline Hyoscine & 26 & 11 & 42 & Drowsiness (11) \\
\hline Meclozine & 12 & 5 & 42 & Drowsiness (4), diarrhoea \\
\hline Magnesium hydroxide (Milk of Magnesia) & 7 & 1 & 14 & Abdominal pain \\
\hline Piperazine & 18 & 4 & 22 & Diarrhoea (3), sleep disturbance \\
\hline Senna (Senokot) & 4 & 2 & 50 & Abdominal pain (2) \\
\hline \multicolumn{5}{|c|}{ Central nervous system } \\
\hline Carbamazepine & 4 & 1 & 25 & Memory loss : \\
\hline Ergotamine tartrate (Migril) & 9 & 2 & 22 & Drowsiness (2) \\
\hline Sodium valproate & 11 & 4 & 36 & Headache (2), dizziness, memory loss \\
\hline \multicolumn{5}{|c|}{ Analgesics and sedatives } \\
\hline Aspirin & 540 & 9 & 2 & $\begin{array}{l}\text { Drowsiness (5), abdominal pain (2), } \\
\text { aggressiveness (2), vomiting }\end{array}$ \\
\hline Chlorpheniramine & 17 & 3 & 18 & Drowsiness (2), aggressiveness \\
\hline Paracetamol & 321 & 9 & 3 & Drowsiness (7), irritability, aggressiveness \\
\hline Promethazine & 93 & 35 & 38 & Drowsiness (35), dry mouth (2) \\
\hline Terfenadine & 6 & 1 & 17 & Headache \\
\hline Trimeprazine & 5 & 2 & 40 & Drowsiness (2), irritability \\
\hline \multicolumn{5}{|c|}{ Decongestants and cough linctuses } \\
\hline Triprolidine and pseudoephedrine (Actifed) & 185 & 69 & 37 & Drowsiness $(68)$, dizziness \\
\hline Citric acid and sodium bicarbonate (Andrews Liver Salt) & 7 & 1 & 14 & Vomiting \\
\hline Ammonium chloride and diphenhydramine hydrochloride (Benylin) & 80 & 7 & 9 & Drowsiness (6), vomiting \\
\hline Squill liquid extract (Buttercup Syrup) & 13 & 1 & 8 & Drowsiness \\
\hline Brompheniramine maleate (Dimotane and Dimotapp) & 32 & 4 & 13 & Drowsiness (4) \\
\hline Pseudoephedrine hydrochloride (Linctifed) & 11 & 3 & 27 & Drowsiness (3) \\
\hline Diphenhydramine hydrochloride (Lotussin) & 10 & 2 & 20 & Drowsiness, irritability \\
\hline Paracetamol and promethazine hydrochloride (Medised) & 6 & 2 & 33 & Drowsiness, dizziness \\
\hline Xylometazoline hydrochloride (Otrivine) & 19 & 1 & 5 & Vomiting \\
\hline Guaiacol and codeine (Pulmo Bailly) & 2 & 2 & 100 & Vomiting (2) \\
\hline Opium (Opiate Squill Linctus) & 1 & 1 & 100 & Shakiness \\
\hline Pseudoephedrine hydrochloride (Sudafed) & 35 & 1 & 3 & Drowsiness \\
\hline Terpin hydrate (Terpoin) & 3 & 2 & 67 & Drowsiness (2) \\
\hline Promethazine hydrochloride (Tixylix) & 19 & 1 & 5 & Drowsiness \\
\hline Phenylpropanolamine hydrochloride (Triominic) & 2 & 1 & 50 & Drowsiness \\
\hline Phenylpropanolamine hydrochloride (Triotussic) & 2 & 1 & 50 & Drowsiness \\
\hline
\end{tabular}

They were asked to differentiate, where possible, between effects caused by drugs and those due to illness. Adverse reactions were not recorded if the effect and the indication for the drug's use were similar. The distribution of social classes and the sex ratio were similar to those in the general population. There was a mean of 93 children in each one year age group; more than 100 children were in each year group from 3 to 11 years. Each child was surveyed for a mean of 11 weeks.

The children received drugs in $2754(14 \%)$ of the weeks surveyed, and adverse reactions to drugs were recorded in $270(9.8 \%)$ of those weeks. Eighteen different adverse reactions in 235 events were recorded (table). Drowsiness accounted for $160(68 \%)$ of these. Three drugs - triprolidine hydrochloride and pseudoephedrine (Actifed), promethazine, and hyoscine-caused the highest incidence of adverse reactions of all the drugs and were responsible for 114 cases $(71 \%)$ of drowsiness. Twenty three adverse reactions $(10 \%)$ were episodes of diarrhoea, and antibacterial drugs were implicated in $17(74 \%)$ of these. The table lists the 38 drugs that reportedly caused adverse reactions.

\section{Comment}

The definition of an adverse reaction to a drug-an undesired or unintended response to a drug - was the same as that used in studies in which adverse reactions have been reported by nurses, ${ }^{12}$ pharmacists, and doctors. ${ }^{23}$ The incidence of adverse reactions as recorded and reported by parents in this survey-9.8\% of the weeks during which drugs were takenis similar to that found in hospital studies, in which the incidence of adverse reactions to drugs for each child admitted has varied from $5 \cdot 2 \%$ to $17 \cdot 2 \% .^{1 \cdot 3}$ The most commonly reported adverse reactions of drowsiness, diarrhoea, and abdominal pain in this survey, however, differ from those of hospital based studies, in which rash, drowsiness, vomiting, and bone marrow suppression have been the most common..$^{1-3}$

This survey was carried out before the introduction of the limited list of drugs available at National Health Service expense in 1985. Drugs that are now excluded were responsible for $43 \%$ of all the adverse reactions that we saw. Cough linctuses and expectorants were common causes. Our results, and the fact that their clinical usefulness remains unproved, seem to vindicate the decision to exclude them.
An appreciation by parents and children that adverse reactions to drugs are common, though usually mild, may lead to a reduction in compliance or an alteration in patterns of self treatment.

Our results suggest that further consideration should be given to certain aspects of drug use in children. In addition to verbal advice, written information, such as package inserts or more comprehensive labelling, may be useful. The role of community pharmacists in advising about treating children with drugs could be more widely recognised in their training. Doctors might consider whether their present apparent reluctance to give parents specific prospective advice on the likely occurrence of common adverse reactions to drugs is appropriate.

MER was supported by a grant from the Mason Medical Research Foundation. REC was supported as a research nurse by the Children's Hospital Centenary Research Fund, Birmingham.

1 Boston Collaborative Drug Surveillance Programme. Drug surveillance: problems and challenges. Pediatr Clin North Am 1972;19:117-30.

2 Whyte J, Greenan E. Drug usage and adverse drug reactions in paediatric patients. Acta Paediat Scand 1977;66:767-75.

3 Choonara IA, Harris F. Adverse drug reactions in medical patients. Arch Dis Child 1984;59:578-80. 4 Macukanovic P, Rabin DL, Mabry JH, Simic D. Use of medicines. In: Kohn R, White KL, eds. Health care: an international study. Oxford: Oxford University Press, 1976:223-77.

5 Bryant BG, Mason HL. Non-prescription drug use among hospital paediatric patients. Am $\mathcal{f}$ Hosp Pharm 1983;40:1669-73.

(Accepted 23 January 1987)

Children's Hospital, Ladywood Middleway, Birmingham B16 8ET

C G WOODS, MB, MRCP, registrar

M E RYLANCE, SRN, HVC, research nurse

R E CULLEN, SRN, RSCN, research nurse

$G$ W RYLANCE, MB, MRCP, consultant in paediatrics and paediatric clinical pharmacology

Correspondence to: Dr Rylance. 